\title{
Increasing Brand Trust through Marketing Communication and Its Impact on School principal's Loyalty
}

\author{
Nasib $^{1}$, Helena Louise Panggabean ${ }^{2}$, Rafida Khairani ${ }^{3}$, Zulia Rifda Daulay ${ }^{4}$, Widy \\ Hastuty $\mathbf{H S}^{5}$

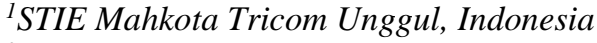 \\ ${ }^{2}$ Universitas Mohammad Husni Thamrin Jakarta, Indonesia \\ ${ }^{3}$ Universitas Prima Indonesia \\ ${ }^{4,5}$ Politeknik Unggul LP3M, Indonesia \\ nasibwibowo02@gmail.com
}

\begin{abstract}
The purpose of this study is to determine the effect of communication marketing on school principal loyalty through brand trust. The approach in this research was quantitative. The data were obtained through a questionnaire with the Likert scaling technique. The population and sample in this study was 45 principals of high school, vocational and Aliyah private schools in Binjai and Langkat district. The sampling technique was accidental sampling was 45 respondents. The results showed that 1) marketing communication has a significant effect on brand trust. 2) Marketing communication has no effect on principal loyalty. 3) Student brand trust has a significant effect on the principal's loyalty. 4) Marketing communication has a significant effect on principal loyalty through brand trust.
\end{abstract}

Keywords

communication; trust; loyalty

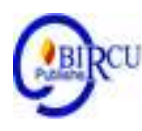

\section{Introduction}

Education is one way to produce quality Human Resources (HR) with experience changes in knowledge, skills and attitudes. These changes can be a capital to improve selfcompetence in facing the era of globalization that always undergoes the change (Sitorus et al, 2019). Higher education, both public and private, has the task to form human resources who are ready to use in the world of work. This demand is much needed by the public/ community who wants to provide good provisions for their children (Candera, 2019). This makes universities continue to make improvements by adjusting the curriculum to meet the needs of the industrial world. The purpose of these activities is that alumni have readiness to enter the world of work (Pattiwaellapia, 2020). In addition, universities also continue to invest in human resource development by providing educational scholarships to lecturers and staff so that the availability of lecturers and staff to facilitate the needs of the wider community can be counted on.

Loyalty to higher education can come from students, lecturers or staff. Loyalty makes students, lecturers and staff sincerely want to recommend their closest relatives or friends to study at higher education (Ichsan, 2020). The survival of a university cannot be separated from existing loyalty (Candera, 2019). Building loyalty to students, lecturers and staff is not an easy and short term job, but requires long period of time and strong commitment from all parties, both management and foundations (Sunny, 2020). Loyalty does not only come lecturers and college staff but also from the school principal of SMA, SMK and Aliyah who have a strong desire to recommend their students to study at certain 
universities. Higher education institutions will continue to make some efforts to make the loyalty keep exist or make it increase.

The school principal's loyalty has a tendency to direct students in choosing universities. It is not uncommon for educational foundations conduct kindergarten, elementary, junior high, high school to tertiary institutions (university). School principals and teachers will try to get students who graduate in their SMA, SMK or Aliyah to attend the colleges in the same foundation. Unless there are students who are admitted to enter Government University, the school principal and teachers are unable to prevent it.

Many foundations have no complete level of education (since kindergarten to universities), it makes universities do promotion through school visit (Sutrisno, 2019). However, for foundations with complete level of education, they will not provide opportunities for other universities to enter their high school for promotion. These foundations will block access from other universities in influencing their students. This policy is taken so that students do not get outside influence regarding the excellence of a particular university.

The inclination of a school principal in higher education will not be the same from one another (Kurniawat, 2018). Some marketers of University come to school with a letter of agreement. In general, the content of the agreement letter is about the university provides a reward if there is any student who study in their University. In addition, universities are also willing to become partners in giving training for teachers and students. Community service programs are also often carried out by universities to introduce the advantages to study in their University. However, not all school principals are loyal to higher education even though they have signed the agreement. The principal only hopes that all the graduates from the school that he manages can continue with higher education. The existing agreement letters are generally not binding the principal, but only for the convenience of University to have access in visiting the schools.

Marketing communication has an important meaning in forming a consumer's brand trust (Widajanti, 2020). Good communication will be able to make a consumer have a strong belief that the product or service he choose is right (Muharman, 2020). Marketing communication has a mix communication that can be chosen by universities in increasing the number of new students (Nasution, 2020). This depends on the financial and human resource capabilities of each university (Basri, 2021). However, direct selling by making school visit for promotion by delivering attractive presentation is the most dominant strategy to choose (Nasib, 2019).

\section{Review of Litrature}

\subsection{Customer Loyalty}

Customer loyalty is a customer commitment that can be held by a company in deciding which product to choose even though customers get a lot of stimulus from products with other brands (Keller, 2012). Loyalty of a customers will not exist without the purchase process, as loyalty is also formed because of the impression of quality and experience in consuming the performance of a product or service (Robyardi, 2019). The greater the satisfaction received by consumers and the higher the value of customer loyalty, the greater the profits the company will get. However, customer satisfaction is also strongly influenced by the attitudes and behavior of consumers themselves (Romdonny, 2019) 


\subsection{Brand Trust}

Trust is the desire of a customer to rely on other people as we have a strong level of confidence in him. The important key in increasing high trust in a company or organization is the achievement of results (Djawoto, 2017). Furthermore, trust is defined as an awareness and feeling that consumers have to trust on a product, and service providers use as a tool to build long-term relationships with consumers (Ogi, 2016). Customers who have a good level of trust will have the urge to recommend others in choosing a brand (Subagyo, 2019).

\subsection{Marketing Communications}

Marketing communication can be interpreted as a media in conveying messages to customers in order to increase knowledge and awareness of company products (Susanto, 2019). Marketing communication also has a function to persuade, remind consumers, either directly or indirectly of the company's products (Keller, 2012). Marketing communication is expected to be able to change the cognitive, affective, and conative of a customer (Schiffman, 2012).

\subsection{Theoretical Framework}

The framework in this research is as follows:

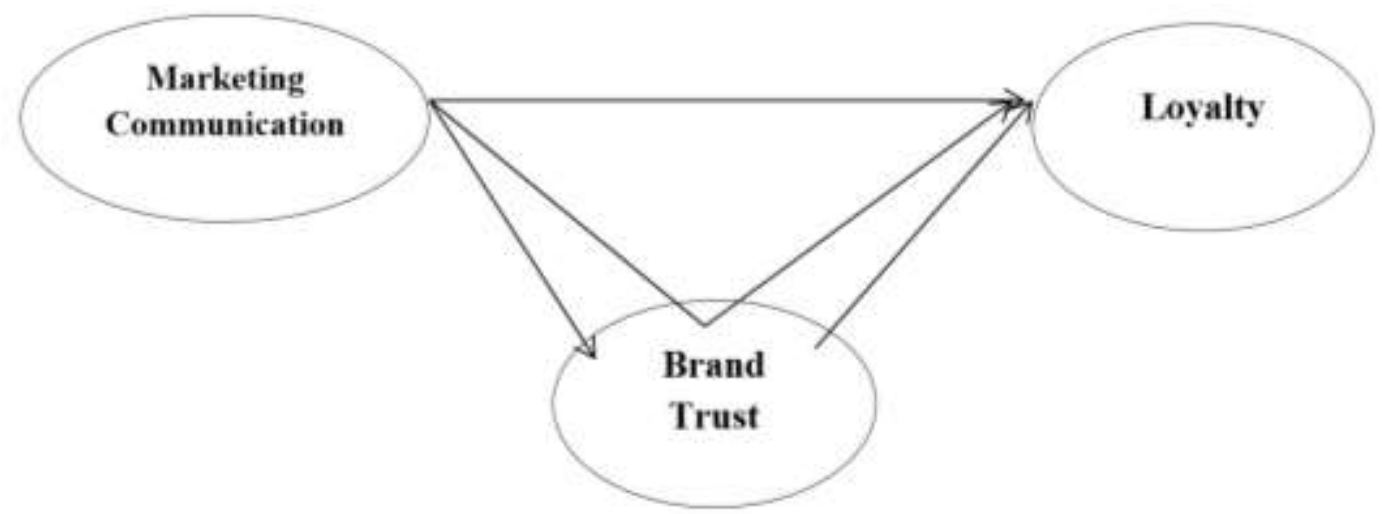

Figure 1. Theoretical Framework

\subsection{Hypothesis}

The research hypothesis is as follows:

1. Marketing communication affects brand trust

2. Marketing communication affects loyalty

3. Brand trust affects brand trust

4. Marketing communication affects loyalty through brand trust

\section{Research Methods}

The type in this research is quantitative. Data analysis using path analysis. The variables in this study are marketing communication, brand trust and loyalty. The population and sample in this study are 45 school principals of SMA, SMK, Aliyah private schools in Binjai and Langkat City. The sampling technique used is purposive random sampling. The study believes that the selected sample of 45 respondents can represent the problem in this study, which is the principal's loyalty to tertiary institutions (University). 


\section{Results and Discussion}

\subsection{Measurement Model Analysis (Outer Model)}

\section{a. Convergent Validity Test}

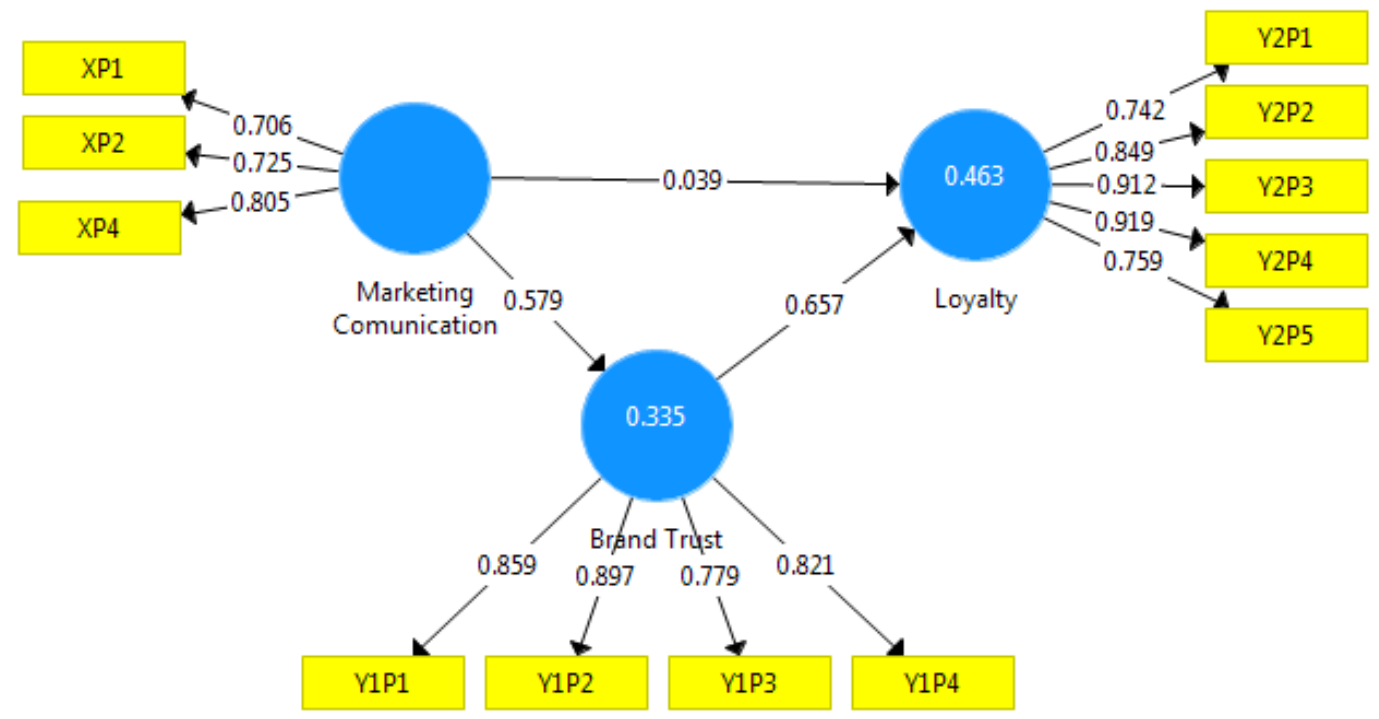

Figure 2. Outer Model Result

\section{b. Construct Reliability Test}

Based on the picture above, we can find that all indicators in the model is $<0.7$. So that it can be declared that it is reliable for measuring the research variables. Then it can be used in the next analysis.

The results of data processing show that:

Table 3. Construct Reliability

\begin{tabular}{|l|c|c|}
\hline Variable & $\begin{array}{c}\text { Composite } \\
\text { Reliability }\end{array}$ & $\begin{array}{c}\text { Average Variance } \\
\text { Extracted (AVE) }\end{array}$ \\
\hline Marketing Communication & 0.514 & 0,557 \\
\hline Brand rust & 0.860 & 0.706 \\
\hline Loyalty & 0.893 & 0.705 \\
\hline
\end{tabular}

Based on table 3, it shows that the average value is $>0.5$. Then the composite reliability value $>0.7$. So, it can be concluded that the indicators in the study are able to measure well.

\subsection{Measurement Model Analysis (Inner Model)}

a. Coefficient of Determination (R2)

Table 4. R Square

\begin{tabular}{|l|r|r|}
\hline Variable & R Square & R Square Adjusted \\
\hline Brand Trust & 0.335 & 0.320 \\
\hline Loyalty & 0.463 & 0.436 \\
\hline
\end{tabular}


Based on data from table 4, it is known that the value of $\mathrm{R}$ Square Adjusted for brand trust variables is 0.320 or $32 \%$, while the remaining $48 \%$ is influenced by other variables which is not the variables of this study. Then for the loyalty variable the value of $\mathrm{R}$ Square Adjusted is 0.436 or $43.6 \%$, while the remaining $56.4 \%$ is influenced by other variables which is not included in this study.

\section{b. Predictive Relevance (Q2)}

The value of Q2 has the same meaning with the coefficient of determination (RSquare). Q- large Value Square $(\mathrm{Q} 2)=0$ indicates the model has Predictive relevance, while if a value $(\mathrm{Q} 2)$ is less than $<0$, this indicates the model has less Predictive relevance; or in other words, when the values of Q2 are higher, the model can be considered as a better fit to the data. Consideration value of Q2 can be done as follows

$\mathrm{Q}_{2}=1-\left(1-\mathrm{R}_{1}^{2}\right)\left(1-\mathrm{R}_{2}^{2}\right) \ldots\left(1-\mathrm{R}_{\mathrm{n}}{ }^{2}\right)$

$\left.\mathrm{Q}_{2}=1-(1-0.320) 1-0.436\right)$

$\mathrm{Q}_{2}=1-(0.68)(0.564)$

$\mathrm{Q}_{2}=1-0.383$

$\mathrm{Q}_{2}=0.616$

Based on these results, the Q2 value is 0.616. It means, all variables in this study, marketing communication, brand trust and loyalty contribute to authenticity data in the existing structural model as much as $61.6 \%$. Then the remaining 38.4 needs to be developed apart from research variables.

\section{c. Effect Size (F2)}

Effect Size (F2) is to determine the proper of the model, whether the predictors of the variable have a weak, moderate, or strong influence at the structural level.

Table 5. Effect Size (F2) test

\begin{tabular}{|l|c|c|}
\hline & Brand Trust & Loyalty \\
\hline Marketing Communication & 0.505 & 0.002 \\
\hline Brand Trust & & 0.533 \\
\hline
\end{tabular}

Based on table 5, it shows that marketing communication has a very weak effect on loyalty, while marketing communication and brand trust have a moderate effect on loyalty.

Table 6. Hypothesis Test

\begin{tabular}{|l|l|l|l|l|l|l|}
\hline Hypothesis & $\begin{array}{l}\text { Original } \\
\text { Sample (O) }\end{array}$ & $\begin{array}{l}\text { Average } \\
(\mathrm{M})\end{array}$ & (STDEV) & $\begin{array}{l}\mathrm{t} \\
\text { Statistics }\end{array}$ & $\begin{array}{l}\text { P } \\
\text { Value }\end{array}$ & Conclusion \\
\hline $\begin{array}{l}\text { Marketing } \\
\text { Communication- } \\
\text { Brand Trust }\end{array}$ & 0.579 & 0.602 & 0.084 & 6.871 & 0.000 & Significant \\
\hline $\begin{array}{l}\text { Marketing } \\
\text { Communication - } \\
\text { Loyalty }\end{array}$ & 0.039 & 0.040 & 0.150 & 0.263 & 0.793 & Insignificant \\
\hline Brand Trust-Loyalty & 0.657 & 0.667 & 0.144 & 4.561 & 0.000 & Significant \\
\hline $\begin{array}{l}\text { Marketing } \\
\text { Communication- } \\
\text { Brand Trust- Loyalty }\end{array}$ & 0.127 & 0.138 & 0.171 & 0.329 & 0.482 & Insignificant \\
\hline
\end{tabular}




\subsection{The Effect of Marketing Communication on Brand Trust}

The results of data analysis show that marketing communication has a significant effect on brand trust. The statistical $t$ value is $6,871>t$ table 2,015 with a significance value $0.000>0.05$. The results of this study are in accordance with the results of research conducted by (Dragos, 2016)(Chinomona, 2016) (Skare, 2019) which states that marketing communication has a significant effect on brand trust. Furthermore, the findings in this study indicate that marketing communication will be various among private universities. Private universities that own their luxurious buildings, have excellent accreditation, possess lecturers with doctoral qualifications, they need only to optimize social media by sharing activities that have been carried out by the university. However, for private universities with buildings that look ordinary, good accreditation, and lecturers who only have master's degrees will make direct visits to schools by presenting their strengths. Private universities will also try to build communication through telemarketing activities. This will continue until the deadline for the closing of new student admissions.

The brand trust of a school principal will get better when the agreements in the agreements letter are properly executed. A school principal certainly does not have a control function when students register to certain private university. It needs good ethics, especially private universities, to be able to provide rewards to school principals when there are any activities at the target schools. For example, when the school commemorates Independence Day. In this situation, private universities provide donations such as trophies, books, pens or phone vouchers as a form of support to their target school.

\subsection{The Effect of Marketing Communication on Loyalty}

The results show that marketing communication had no effect on the loyalty of a school principal. These results can be seen from the $t$ statistical value of $0.263<t$ table 2.015 then a significant value of $0.793>0.05$. The results of this study are not in line with the results of research conducted by (Agus Budi Purwanto, 2016)(Herwan Nafil, 2019)(Susanto, 2019) which states that marketing communication has a significant effect on customer loyalty. The implication researchers get is that good communication between private universities and schools principals will make a principal of the school recommend it to the students. The principal considered that the decision to continue and the University chosen by the students are the right of students and parents. If there are other universities propose a cooperative relationship, the school principals still have right to accept it. However, the school will not guarantee that the students will choose to study at the university.

\subsection{The Influence of Brand Trust on Loyalty}

The results show that brand trust had a significant effect on the loyalty of a school principal. These results can be seen from the statistical value of 4.561> 2.015 and a significance value of $0.000<0.05$. The results of this study are in line with (Nuralam, 2018)(Arif, 2020)(Nasution, 2020) which states that brand trust can increase customer loyalty. The implication of the findings in this study is that the principal will help to recommend a certain college when the alumni from the college are proven capable of being accepted to work in prestigious company. Although the private university will give rewards to the principal when students choose to study at the private university, the principal will be happy to direct the students even if they do not get the reward. The school principal will not ask for a reward in the form of material, but the school will ask the university to participate in providing the facilities and infrastructure needed by the students. 


\subsection{The Effect of Marketing Communication on Loyalty Through Brand Trust}

The results show that brand trust has no a role in mediating marketing communication on the principal's loyalty. These results can be seen from the t statistic value of 0.329 <from t table 2.015 and a significant value of $0.482>0.05$. The results of this study are in line with the results of research conducted by (Amalina, 2016)(Arenggoasih, 2016)(Widajanti, 2020)(Ruslim, 2021) which states that brand trust has a role in mediating marketing communication towards the loyalty of school principals. The implication of the findings is that when private universities are able to build good communication to the target school or partner universities and provide an example of one of the proofs of alumni who have been accepted to work at prestigious companies or government department, this will have an impact on the willingness of the schools principals to recommend the students to continue their education to these private university.

\section{Conclusion}

Based on the results of the research, the conclusions that can be drawn are 1) marketing communication has a significant effect on brand trust. 2) Marketing communication has no effect on principal loyalty. 3) Student brand trust has a significant effect on the principal's loyalty. 4) Marketing communication has a significant effect on principal loyalty through brand trust.

\section{References}

Agus Budi Purwanto, U. W. (2016). Model Pengembangan Komunikasi Pemasaran Dan Kualitas Produk Dalam Rangka Meraih Kepercayaan Dan Loyalitas Konsumen (Studi Pada UMKM Di Kota Semarang). Jurnal Fokus Ekonomi, 11(2), 51-70.

Amalina, A. (2016). Pengaruh Social Media Marketing Terhadap Brand Loyalty Dengan Brand Trust Sebagai Variabel Intervening (Studi Pada Follower Twitter Mizone @ Mizoneid). Jurnal Ilmu Manajemen, 4(3), 1-12.

Arenggoasih, W. (2016). Pengaruh Brand Communication, Service Quality Dan Brand Personality Anggota Dewan Terpilih Melalui Brand Trust Terhadap Brand Loyalty Pemilih (Studi Partai Politik Gerindra). Jurnal Interaksi, 5(2), 123-135.

Arif, M. (2020). Pengaruh Kepercayaan Terhadap Loyalitas Nasabah Melalui Kepuasan Sebagai Variabel Intervening Produk Tabungan Emas Pegadaian. Jurnal Ilmu Manajemen (JIM), 8(2), 472-481.

Basri, T. S. A. I. (2021). Aktiva Jurnal Manajemen dan Bisnis Pengaruh Komunikasi Pemasaran Terpadu Terhadap Keputusan Pembelian di Ace Hardware Yogyakarta. Jurnal Manajemen Dan Bisnis, 1(1), 26-34.

Candera, G. H. M. (2019). Dimensi Kualitas Layanan dan Pengaruhnya terhadap Loyalitas Mahasiswa dengan Tingkat Kepuasan sebagai Variabel Intervening. Jurnal Manajemen Bisnis Krisnadwipayana, 7(2), 104-112. https://doi.org/10.35137/jmbk.v7i2.254

Chinomona, R. (2016). Brand Communication, Brand Image and Brand Trust as antecedents of Brand Loyalty in Gauteng Province of South Africa. African Journal of Economic and Management Studie, 1-28.

Djawoto, P. D. R. (2017). Analisis Pengaruh Kepercayaan, Kemudahan, dan Kualitas informasi Terhadap Keputusan Pembelian Secara Online di KASKUS. Jurnal Ilmu Dan Riset Manajemen, 6(10), 1-20. 
Dragos, G. O. O.-E. Pl. C. (2016). Conceptual Model Regarding The Influence Of Social Media Marketing Communication On Brand Trust, Brand Affect And Brand Loyalty. Economic Computation and Economic Cybernetics Studies and Research, 50(1), 141-156.

Herwan Nafil, N. (2019). Optimalisasi Kepuasan Pelayanan Dan Komunikasi Pada Supermarket Mr. Ben Medan. Juranl Ekonomi Dan Kebijakan Publik, 4(2), 111-118.

Ichsan, L. N. R. N. (2020). Sosialisasi Pemasaran Dalam Meningkatkan Loyalitas Mahasiswa Dan Alumni Fakultas Hukum Universitas Simalungun. Jurnal Pengadian Kepada Masyarakat Maju Uda Medan Sumatera Utara, 31-36.

Keller, P. K. K. L. (2012). Manajemen Pemasaran Edisi 12. Jakarta: Erlangga.

Kurniawat, E. (2018). Pengaruh Kepercayaan, Kebiasaan Menggunakan Produk Terhadap Kepuasan Konsumen Serta Loyalitas Konsumen Dalam Membeli Merek Samsung Di Toko "Y." Jurnal Ilmiah Ekonom, 201-212.

Muharman, C. P. S. R. F. S. D. (2020). Brand Trust Variable Goes Beyond the Marketer Persuasion Causality in the Decision of Choosing a College. Bricolage: Jurnal Magister Ilmu Komunikasi, 6(1), 65-83.

Nasib, E. H. S. (2019). The Decision of Choosing Course in the Era of Covid 19 through the Telemarketing Program, Personal Selling and College Image. Budapest International Research and Critics Institute-Journal, 3(4), 2843-2850.

Nasution, S. L. N. C. H. L. D. A. R. (2020). Pengaruh Kualitas Produk, Citra Merek, Kepercayaan, Kemudahan, Dan Harga Terhadap Keputusan Pembelian Pada ECommerce Shopee (Survei pada Mahasiswa S1 Fakultas Ekonomi Jurusan Manajemen Universitas Labuhan Batu). Ecobisma (Jurnal Ekonomi, Bisnis Dan Manajemen), 7(1), 43-53. https://doi.org/10.36987/ecobi.v7i1.1528

Nuralam, N. A. A. F. D. I. P. (2018). Pengaruh Kepuasan Pelanggan, Biaya Beralih, Dan Kepercayaan Merek Terhadap Loyalitas Pelanggan (Survei pada Pengguna Kartu Operator Seluler Simpati pada Mahasiswa Jurusan Ilmu Administrasi Bisnis Angkatan 2015/2016 dan 2016/2017 Fakultas Ilmu Administrasi. Jurnal Administrasi Bisnis (JAB), 64(1), 92-101.

Ogi, F. D. S. M. I. W. J. (2016). Pengaruh Kualitas Pelayanan, Kualitas Produk Dan Kepercayaan Terhadap Kepuasan Konsumen (Studi Pada PT. Fifgroup Cabang Manado). Jurnal Riset Ekonomi, Manajemen, Bisnis Dan Akuntansi, 4(1), 109-119.

Pattiwaellapia, O. S. (2020). Bagaimana Kualitas Pelayanan dan Fasilitas Belajar dapat Mempengaruhi Loyalitas Mahasiswa dengan Mediasi Kepuasan Mahasiswa? BIEJ: Business Innovation \& Entrepreneurship Journal, 2(4), 252-262.

Robyardi, E. H. E. (2019). Kajian Empiris Kualitas Layanan Terhadap Loyalitas Yang Dimediasi Oleh Kepuasan Mahasiswa (Studi Kasus pada UPT Perpustakaan Universitas PGRI Palembang). Jurnal Media Wahana Ekonomika, 15(4), 1. https://doi.org/10.31851/jmwe.v15i4.3049

Romdonny, J., and Rosmadi, M.L.N. (2019). Factors Affecting Customer Loyalty in Products. Budapest International Research and Critics Institute-Journal (BIRCIJournal). P. 337-343.

Ruslim, M. T. T. S. (2021). Pengaruh Komunikasi Dan Citra Merek Terhadap Loyalitas Merek Dengan Kepercayaan Sebagai Mediasi. Jurnal Manajerial Dan Kewirausahaan, III(1), 236-244.

Schiffman, L. G. K. (2012). Consumer Behaviour. USA: New Jersey Prentice Hall.

Sitorus, H.V., et al (2019). The Effect of Learning Strategy and Thinking Ability on the Students' Learning Outcomes in Economics Subject of XI Social Students in Senior 
High School State 1 in Pematang Siantar. Budapest International Research and Critics in Linguistics and Education (BirLE) Journal. P. 451-460.

Skare, M. S. Đ. O. D. V. (2019). How Can Perceived Consistency In Marketing Communications In Fl Uence Customer-Brand Relationship Outcomes? European Management Journal Journal, Oktober(2), 1-9. https://doi.org/10.1016/j.emj.2019.08.011

Subagyo, A. D. D. I. N. S. H. D. (2019). The Effect of Brand Image and Brand Trust on Customer Satisfaction and Customer Loyalty of Ara Shop Sidoarjo. Journal of World Conference (JWC), 1(2), 257-262. https://doi.org/10.29138/prd.v1i2.149

Sunny, D. N. B. K. P. A. P. M. P. (2020). Peran Kualitas Layanan Dalam Menciptakan Loyalitas Mahasiswa. Jurnal Widya Manajemen, 2(1), 10-27.

Susanto, B. B. D. (2019). Pengaruh Komunikasi Pemasaran Dan Motivasi KOnsumen Terhadap Keputusan Siswa Untuk Kuliah Di Aademi Komunitas Dharma Bhakti Bangka. Jurnal Ekonomi Dan Manajemen STIE Pertiba Pangkalpinang, 5(1), 12-21.

Sutrisno, E. (2019). Pengaruh Bauran Promosi Terhadap Keputusan Mahasiswa Kuliah Di Sekolah Tinggi Teknologi Kedirgantaraan (Sttkd) Yogyakarta. Jurnal Ilmu Manajemen Dan Akuntansi Terapan (JIMAT), 10(1), 43-60.

Widajanti, O. R. A. S. E. (2020). Pengaruh Komunikasi Merek Terhadap Loyalitas Merek Melalui Kepercayaan Merek Sebagai Pemediasi (Survei pada Konsumen Kecap Lombok Gandaria Merah di Luwes Kestalan Surakarta). Jurnal Manajemen Sumber Daya Manusia, 13(1), 52-67. 